\title{
Going through the Motions
}

\author{
Half-Hearted Courtship and the Topology \\ of Queer Shame
}

How does death queer the amorous pursuits sought in its aftermath, and how should we understand the outpouring of hope and disenchantment that ensues? After he fails to save Yūgao, Genji tries to move on, chasing new women in part to repress the humiliation he suffered in the haunted house. This leads him to a similarly remote but less foreboding residence to which he steals in hopes of bedding a mysterious princess named Suetsumuhana. As it turns out, however, Genji is not alone in his pursuit; Tō no Chūjō trails him to the woman's neglected residence. Miffed that Genji would disguise himself to go gallivanting without him, Tō no Chūjō spies his frenemy's flirtations from gaps in the woman's fraying hedges before confronting him petulantly at the manor's periphery. This chapter examines sites at which such encounters occur to understand better how queer gestures traverse the borders of built-space, thus resituating the previous chapter's discussion of masculinity's shifting landscape.

Here, especially, the narrative makes a farce of Heian romantic ideals and protocol in a manner that lends itself to queer reading. Genji and Tō no Chūjō enter a triangular relationship with Suetsumuhana in which they pursue the same inaccessible woman to intensify their ties to one another. This situation presents a classic example of the mimetic desire and competition Eve Sedgwick theorizes in Between Men, where men's battle in heterosexual courtship builds homosocial intimacy between them. Hence the reclusive Suetsumuhana acts as a conduit that augments Genji and Tō no Chūjō’s connection. For Doris Bargen, "Courtship here is a contest between the two men that seems to bind them to each other rather than to the woman, thus leaving the kinship ties between the brothers-in-law unchanged." ${ }^{\text {Y }}$ Yet simultaneously, Suetsumuhana's outmoded wardrobe, dilapidated residence, and reluctance to devote herself to courtship rituals mark her as a queer figure who 
fails to snap into the Heian marriage machine. Therefore, I argue that Suetsumuhana's very bearing and dwelling call Heian ideals into question.

Cast as hopeless when it comes to courtship, Suetsumuhana triggers shame and frustration for those connected to her, who bemoan her abstention from the system governing their aspirations. Whereas feminist readings of Genji might posit Suetsumuhana as an agentive refuser of courtship, I instead highlight her atypical disinterest in sex-a queer disposition threatening enough that it needs to be discredited by shaming her. In considering Suetsumuhana, I recuperate her queerness as a generatively unsettling mode of inhabiting a world hostile to the detachment she embodies. Less a willful stance than a hapless posture, Suetsumuhana's bearing figures a queer approach to residing otherwise within an unforgiving Heian world.

\section{REVISING HOMOSOCIALITY IN THE TRANSITION \\ FROM "YŪGAO" TO "SUETSUMUHANA"}

The previous chapter showed both how devastating Yūgao's death was for Genji and how that devastation grounded a thriving intimacy with his servant, Koremitsu. Koremitsu still has his role to play beyond the "Yūgao" chapter. However, in "Suetsumuhana," the temperamental rapport between Genji and his brother-in-law, main friend, and rival, Tō no Chūjō, becomes the male homosocial relationship stressed most by the narrator, alongside the female homosocial rapport between Suetsumuhana and her breast-sibling (menotogo), Taifu. Although we got hints of Koremitsu's begrudging willingness to back off and let Genji court Yūgao, we also understand how the clear status difference between master and servant framed-and likely necessitated-such romantic unselfishness. But with Tō no Chūjō, things are different because of his nearly identical rank in relation to Genji, not to mention their comparable talents: "Accompanying Genji continuously in his comings and goings, Tō no Chūjō joined him day and night for both study and music, his pace nearly neck and neck against Genji's, and tagged along whatever the place, until before he knew it he could no longer maintain his inhibition, unable to conceal from him whatever heartfelt thoughts he had, and became inseparably fond of him."2

Doris Bargen notes that by secretly appropriating Yūgao's daughter with Tō no Chūjō, "Genji tries to repress the multifaceted relationship to Tō no Chūjō by minimizing his proximity in kinship terms." ${ }^{3}$ However, this attempted repression can produce queer effects. Erotic objects can fluctuate within courtship's homosocial mediations to spark other forms of intimacy that might minimize the men's kinship in theory while drawing them closer in practice. Paul Schalow asserts, "If there is one great friendship in the Genji monogatari," this is it: "The exposition of their friendship has a psychological complexity that far surpasses anything seen before in the literature [of the Heian period]."4 This "complexity" involves flirtations and fickle violences that recall Genjis machinations with women. The men's "great friendship" is also a relationship in which seductive ploys 
and emotional games abound, as when Genji shares his erotic correspondence. As Schalow notes,

The text informs us that these are the least significant of Genji's love letters; the important ones Genji has put safely away. The revelation suggests that Tō no Chūjōs discovery of the letters had not been the result of Genji's carelessness but was deliberately orchestrated by him to probe and explore his friend's love life. Genji then issues a challenge to Tō no Chūjō: if you show me your love letters, I'll show you mine. The scene is highly seductive, each man drawing the other into his world of desire. The scene also reveals a certain degree of calculation in the openness Genji allows himself with Tō no Chūjō. ${ }^{5}$

Indeed, Genji's rivalrous friendship with Tō no Chūjō stands as an archetypal male homosocial relationship in the narrative. The two are thick as thieves, and their affection for one another swerves between animated gabbing about the frustrations of courting women and pointed combat in that same arena-with plenty of calculated openness along the way. Vying with each other for the same woman, Suetsumuhana, Genji and Tō no Chūjō adhere to a triangular pattern outlined by Sedgwick in her revision of Rene Girard's schematization of desire, in which "the choice of the beloved is determined . . . by the beloved's already

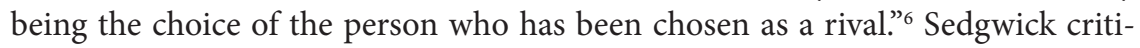
cizes the schema's emphasis on the symmetrical nature of the triangular relation and inattention to the "asymmetrical," "slippery" quality of "the apportionment of forms of power that are not obviously sexual." I follow Sedgwick's impulse to stress the asymmetrical features of male homosociality - such as those seen previously between Genji and Koremitsu-while acknowledging the basic configuration Girard outlines. Ultimately, the interactions transpiring within and around Suetsumuhana's deteriorating estate demonstrate the extent to which that triangular frame winds up overrun by strains of mournful and erotic longing irreducible to rivalrous love.

\section{REDRESSING EMASCULATION BY REVISITING THE RAMSHACKLE ESTATE}

Genji tries to overcome the death of Yūgao by pursuing Suetsumuhana, a princess residing in a rustic, ill-frequented estate, who has been abandoned after her father's death. This new affair gives Genji the opportunity to prove himself more competent at courting than the Yūgao tragedy displayed. According to Aileen Gatten, "The princess is less easy to fit into a set role. She is a complex character, pitiable for her gaucheries but admirable for the staunchness with which she upholds paternal admonitions. Some have wondered if she serves any purpose at all. I suspect that 'Suetsumuhana' was intended as a comic interlude after the tragic events in an earlier chapter, 'Yūgao."' ${ }^{\prime}$ This seems possible, yet Suetsumuhana's residence-"a place so terribly tumbledown and forsaken"-recalls the site where Yūgao died and effectively lets Genji try his hand again. ${ }^{9}$ This time, he needn't 
fear a spirit's attack..$^{10}$ Suetsumuhana's fusty manner and her displacement from the halls of power means she poses no threat in either courtship or the factional politics that fuel it.

Suetsumuhana's appealing harmlessness stems both from her middle-tier status and her crumbling estate. She is neither too pampered nor too lowly to merit disqualification from courtship; her rank suggests that a higher-ranking courtier like Genji might take liberties with her. Her status also hints at charms belonging to the category of "the girl unknown to the world, the surprisingly alluring one shut away alone in some rundown house overgrown with creepers" who is "boundlessly intriguing." " Suetsumuhana's estate, with its middle gate "deplorably warped and apt to collapse [ito itau yugamiyorobohite]," captures Genjis imagination: "This kind of place must be just what those folks meant when they spoke of 'an old gate overgrown with creepers." ${ }_{12}$ Taking in this rickety vista, Genji "went on thinking things like, This is exactly the kind of place where sorts of poignant episodes would occur in ancient tales, but upon thinking he might make overtures toward her he grew sheepish and eased his approach, worried shed think him too brazen." ${ }^{13}$ As it was with Yūgao, Genji's imagination is stoked by fictional texts that suggest the lady of the house might prove ripe prey. That the once stately house has fallen into disrepair suggests a dip in status that might let Genji snag Suetsumuhana at a discount. Although he's not had difficulty securing more elite women, Genji is motivated in part by this one's social decline, the architectural evidence of which accents her exoticism. Weakened walls and fences arouse Genjis curiosity because they promise scopic and physical access to the sexual prize ensconced within.

The boundary's flimsiness arouses the suitor's desire to penetrate the architectural membrane, a prospect all the more inviting given the way Genji's masculine ego took a recent beating at the hands of a jilted apparition. The punctured boundary trope is a well-worn Heian literary device for framing erotic exchange, chiefly in the form of kaimami, in which men, predominantly, derive voyeuristic pleasure from gazing at women through gaps in built or natural borders like fences or hedges. ${ }^{14}$ Yet we should not assume this schema to be absolute, for as Doris Bargen notes, "Confronted with the ever-present possibility of being spied upon, the Heian noblewoman was thoroughly socialized to be on constant alert. ... While scanning the physical boundaries surrounding, concealing, and protecting her, the Heian noblewoman kept an eye on her own impeccable appearance." ${ }^{15}$ Moreover, at a meta-textual level, Edith Sarra asks, "How do we account critically for the fact that the gaze of the hero in the kaimami scene frequently depends on the mediation of feminine narrators and female authors? Who is looking at whom in these scenes?"16

Sarra's question implies a critical vantage taken by the feminine narrator in Genji (if not by the author herself), whose narration plays up this visual paradigm's potential for failure. For indeed, although "Suetsumuhana's" plot setup aligns 
superficially with kaimami's gendered template, the narrative bends that frame to reroute voyeurism's typical vector:

Likely having promised himself at another engagement elsewhere, Genji very discreetly prepared to return home. He snuck off toward the main house, thinking, Perhaps I'll hear some sound from her! When he approached a concealed spot where only the splintered fragments of a see-through fence remained, Genji found another man who'd been standing there the whole time. Who could he be? Some playboy smitten with her, I bet, he thought, adhering to the shadows as he stood there hiding. It was Tō no Chūjō.

This evening, they had both departed the palace together, but once they parted paths and Genji didn't head for His Excellency's or for Nijō, Tō no Chūjō thought it odd and wondered, Where's he off to? trailing him to figure things out, despite having his own place to be. Since he'd come on some offbeat horse and wore an unassuming hunting cloak, Genji couldn't make out who he was. Because Tō no Chūjō had seen Genji enter this altogether unfamiliar place, he was perplexed and stood there listening to the music, eagerly waiting for when Genji emerged, about to leave. Not wanting to be recognized himself, Genji was tiptoeing away when the man neared him without warning. "The misery of your ditching me was such that I thought I'd come serve at your side, sir." ${ }^{17}$

The narrative drops a hint about another (presumably heterosexual) rendezvous only to reveal Tō no Chūjō as the unanticipated partner in the tryst. Genji skulks about, trying to secure the closest vantage from which to spy on "the lady within." ${ }^{18}$ That his spot has already been taken by Tō no Chūjō implies that Tō no Chūjō has clearly been observing Genji's movements up to this point, placing Genji within a nested structure of eroticized surveillance in which he is watched closely even as he clamors for a glimpse of his heterosexual target. Doris Bargen notes that "the threat of discovery makes Genji behave like a woman sensing an unwelcome kaimami." ${ }^{19}$ By adding this layer to the normative "hedge-gap spying" motif, the narrative queers the pattern of male voyeurism to accommodate a portrait of homosocial interchange.

Here, we get a sense of the kaimami motif's utility in stimulating readerly interest. Just as Genji "was irritated, but also found it somewhat amusing once he saw who this figure was," so too might Heian readers have grinned at the trope's transposition. ${ }^{20}$ Despite the normalization of kaimami as a driving component of Heian literary courtship, part of the convention's thrill comes from its illicit character: an element of danger attends the secret peeping. Hirota Osamu explains this risk in terms of kaimami's gendered criminal thrust in Genji. He notes that kaimami constitutes a social and cultural offense by which the secrets of a woman's birth and genealogy will be divulged, making her all the more vulnerable to men. ${ }^{21}$

For Genji's Heian readers-and female ones especially-part of their enjoyment may have stemmed from being able to look on and judge such infractions from a safe remove structurally akin to that of the fictional watcher, as Edith Sarra has suggested. ${ }^{22}$ In a less sophisticated reading, Royall Tyler argues that scenes like 
this actually allowed Heian female audiences reading or hearing the tale to vicariously indulge their fantasies about Genji through an eroticized male gaze:

In short, Murasaki Shikibu could not show her audience a dizzyingly sexy Genji without assuming in the ladies present (perhaps ones far above her in rank) feelings that they could not properly admit to having. ... Still, it would have been a shame not to describe Genji meltingly at all; and that is no doubt why, when he looks good enough to eat, we see him through the eyes of a man. Although in real life men, too, might sometimes have felt that way about a man like Genji, in the tale these male watchers seem to be a device at once decorous and titillating to save the reader's dignity and leave her perfectly free to enjoy the view. ${ }^{23}$

Matters of preserving decorum aside, Tyler's lavish language here deserves a queer reading all its own given the way it curiously deflects the possibility of homoerotic desire while simultaneously acknowledging the socially disorganizing propensity of Genji's "dizzyingly sexy" figure. On that same page, Tyler explains, unconvincingly, that "if these were scenes of homoerotic desire, the theme would be followed up elsewhere in the tale; but it is not. Nothing develops the repeated motif of the male watcher stirred by the sight of an informally dressed, languishing or excited Genji." ${ }^{24}$ Indeed, the very fact that the text deploys this erotic interplay between males as "a repeated motif" should coax us to theorize it seriously instead of dismissing its implications-however dizzying they may be.

The recourse here to a rhetoric of theme to foreclose a fuller consideration of homoerotic desire recalls $\mathrm{H}$. Richard Okada's critique of Japanese literary translation-commentary exploiting theme for its monological, totalizing function, which "deprives a work of its specificity and difference." ${ }^{25}$ In the above passage, Tyler's totalizing gesture emits a homophobic tenor evoking that of the modern scholarship outlined in chapter 1 . In short, Tyler's interpretation might be profitably repurposed toward a reparative reading of homosocial desire that didn't necessarily subsume male homoeroticism beneath female voyeurism and instead treated these options as just two possibilities among many.

Genji's ideal vantage has been usurped by his main rival. That the spot at the tattered fence is "sheltered" (kakure no) implies a modicum of privacy for these men's encounter even though what drew them to the site was, ostensibly, unchecked scopic access to Suetsumuhana's body. A locus of gazing that asymmetrically disposed female bodies to male surveillance morphs here into a crevice capable of hosting an unexpected rendezvous between men. The fragmented fence becomes a porous pretext that queers prevailing romantic tropes through a destabilizing closeness.

The characters' arrangement in space deserves attention. Notice that hedge spying requires an optimal aperture (wide enough to peer through but small enough that the viewer can't be seen) and distance (neither too close nor too far). In this case, the shielded remove from the women's detection grants Genji and his male companion an interval in which to meet outside the strictures of court protocols. The lure of the diminished woman has brought the men together, allowing them to 
sample a fresh proximity to each other. The frayed periphery enables this rapport. ${ }^{26}$ "Standing there the whole time," Tō no Chūjō has been watching and, moreover, waiting for an interruption in the action. He stands within a span of time outside the official clock of court duty or the commonplace imperative to bag a lady of repute. The presence of "some playboy smitten with [Suetsumuhana]" obstructs the clear sight line Genji had expected. ${ }^{27}$ By taking up this "sheltered spot," Tō no Chūjō interposes himself between Genji and Genji's original female object of desire. This unanticipated interference redirects Genji's curiosity: "Who could he be?"

Genji now watches the stranger who has been observing him, "adhering to the shadows as he stood there hiding." ${ }^{28}$ The perforated fence does not merely allow "some playboy" (sukimono) to be "smitten by her" (kokoro kaketaru), it also allows Tō no Chūjō to track Genji's movements undetected. By the same token, Genji's heterosexual desire to peer more deeply into the ladies' den leads him to the periphery, whose very location and permeable nature let lust trickle more malleably toward homoerotic territory.

The pretext of staring at the lady of the house from a proximate remove lets the men enjoy even greater proximity to one another as they each expose the other's secret. Both men are disguised. Tō no Chūjō had "come on some offbeat horse and wore an unassuming hunting cloak," so "Genji couldn't make out who he was." ${ }^{29}$ This misrecognition highlights masquerade's potential to spur encounters that drift past a heterosexual binary. Whatever errand the two men initially set out on drifts off course to mimic cruising, with Tō no Chūjō "trailing Genji to figure things out, despite having his own place to be." ${ }^{\circ}$ This desire to know more of Genji's behavior beyond the confines of the palace gates leads Tō no Chūjō to change into less restrictive robes and abandon his plans so he might pursue Genji instead. Tyler's translation, "rendezvous of his own" for ware mo yukukata aredo, dispels the original text's ambiguity, perhaps at the cost of unduly stressing the romantic, heterosexual character of the outing. The irony here is that in trying to uncover Genji's secret courtship, Tō no Chūjō effectively winds up courting Genji.

\section{CRUISING THE FRINGES OF COURTSHIP}

Curiosity has curved Tō no Chūjō's route to a heterosexual rendezvous. Aroused as much by Genji's change of outfit and surreptitious bearing as by his own chagrin at not being invited to come with, Tō no Chūjō "eagerly lies in wait" (shitamatsu narikeri) until the moment is ripe to confess his intentions. ${ }^{31}$ His exchange with Genji evokes modern cruising tropes. Replace the phrase "his own place to be" (ware mo yukukata) with "discotheque," and the overlap gleams, both in the buildup before Tō no Chūjō reveals himself to Genji and in Tō no Chūjōss wish to accompany him (onokuri-tsukaumatsurituru ha).

For high-ranking courtiers like these, visiting static ladies emplaced behind tiresome layers of hedges and shutters and screens and servants and robes 
occasionally loses its appeal. Suetsumuhana seems remarkably mysterious, thus Genji's secret visit. But intrigue can assume various shapes. And indeed, Genji's desire leaves other shades of longing in its wake. To be sure, the entire complex of erotic relations hinges on how distance is managed between subjects and their objects of desire. When does close become too close? And how might one resolve to close the gap with what is desired? Temporal and spatial intervals-waiting, trailing, watching another man's silhouette lilt in the saddle, wondering what's beneath his unassuming cloak-defer the pleasure of consummating contact to amplify its intensity. These deferrals thicken the plot. They also decouple alignments underpinning Heian marriage politics' routines of social reproduction. This unfastening nudges prototypical Heian literary tropes, like the hedge-gap spying or the moon-viewing motif, out of joint.

On revealing himself, "near[ing] Genji without warning" (futo yorite), Tō no Chūjō composes the following poem:

We were side by side when as friends we took our leave from Palace Mountain.

But now, this sixteenth night's moon shuns showing me where he'll lie. ${ }^{32}$

Within the poem's opening unit (morotomo ni) is embedded tomo (friend/follower), which Gustav Heldt reminds us can mediate homosocial tensions through its dual valence. ${ }^{33}$ "[Taking] our leave," we drift away from the palace's high center and toward a lower, more liminal and hidden spot, where the "sixteenth night's moon shuns showing where he'll lie" (iru kata misenu isayohi no tsuki). As Tō no Chūjō's poem highlights, the men's awkward run-in occurs on the sixteenth night-one night after the full moon.

Whereas the fifteenth night's moon carries celebratory associations of poetic beauty, along with a magnified visibility accompanying strong moonlight, the sixteenth's offers slightly less. Waning height and brightness suits the disenchantment coating this couple's secret rendezvous. Where calibrated sight lines predominantly secure female erotic objects for gazing males, this poem laments the withdrawal of visual access to reproach Genji's concealed retreat from Tō no Chūjō. Like the sixteenth's stepchild moon, Tō no Chūjō has been left to play second fiddle to some dusty maiden.

Still, this lesser moon accentuates other possibilities. Akin to the turn away from palace protocol, this moon's incrementally softer light allows for gentler exposures. Rather than throwing everything open to view, this weaker moon shelters the object of desire sought. Moreover, "where [Genji] will lie" can be read as a metaphor for Genji's secret destination, but its language also carries erotic undertones. The moon (tsuki) can also mean in verb form to "strike" or "penetrate." The term "lie" (iru), meanwhile, denotes insertion, or entrance into the moon's home amid the clouds. Overall, the poem recalls Heldt's claim that "it is precisely the ability of poetic images to arouse desire while deferring recognition of its object that would seem to endow them with aesthetic (and erotic) interest." 34 
Hence, we witness a revelatory instant when the desiring subject dispenses with the shadows to confess his longing to the spying partner. Notice that moment of emergence at which the erotic potential of a homosocial intimacy seeps through. With his curiosity piqued by Genji's suspicious behavior and sudden departure, Tōo no Chūjō seeks out his friendly rival's light, hoping to bask in it away from prying eyes. To determine where the coy moon will set is to locate where Genji will spend the night, and Tō no Chūjō insists on intercepting him there.

Genji's ambivalence at being hunted this way derives from the men's mercurial rapport as well as from embarrassment at being discovered on a night his manly charms have failed to snare the manor's mistress. Although salty, Genji does not rebuff his pseudo-suitor:

Genji was irritated, but also found it somewhat amusing once he saw who this figure was.

"How unthinkable of someone to do this!" he fumed. ...

"What would you do if someone else were to shadow you like this?" Tō no Chūjō countered, upbraiding Genji.

"Truth be told, when you're out here traipsing about like this, having a guard with you is really the more appropriate thing to do. I don't want you leaving me behind. Plus, untoward things could happen with you out prowling in disguise." ${ }^{35}$

His rival then chides Genji by referencing the "Yūgao" debacle, and Genji responds coquettishly with a poem: "Bathing each village alike in its radiance one longs to gaze, but who would search Mount Irusa where the roving moon enters?" 36 Much as the patch of tattered fence delimiting Suetsumuhana's residence alters the standard heterosexual vector of voyeurism, this coy banter at "a concealed spot" along that thinning boundary speaks to such a space's capacity to host erotic poetic exchange between men. To ask "who would search Mount Irusa, where the roving moon enters?" puts to Tō no Chūjō the chiding question of why he has followed Genji in this way. The rhetorical query registers Genji's slight dismay, even as the flirty poem manifests some of the boundary testing taking place across the "Suetsumuhana" chapter's settings more broadly. Genji's reply plays at a "look but don't touch" provision. The line "bathing each village alike in its radiance, one longs to gaze" lets the admirer ogle Genji. The poem grants visual access only to curtail its implied physical consummation, protracting the tart give and take initiated by Tō no Chūjō’s pouty reprimand.

The poem encapsulates a proximate remove through which these men express desire. It establishes a disproportionate ratio between sight and touch, sparking desire for the latter with a coy deferral. The poem preserves distance between "gazing" and "setting/entering," implying an effort by Genji to police the physical boundaries of Tō no Chūjōs affections. At the same time, the men's gender and status grant them parallel degrees of mobility that make such aims difficult to achieve. The linked amusement and annoyance Genji feels stems from 
this difficulty. The freedom of movement both men share opens each up to pursuit and capture by the other. Neither man wants to be lonely or denied; each man has the pluck and means to prevail on his rival.

\section{BITTERSWEET ASYMMETRIES AND FANTASIES \\ OF DOMINATION}

Tō no Chūjō announces his displeasure under the pretext of concern for Genji's safety and reputation. In truth, Genji's secret jaunt unnerves Tō no Chūjō. If he can't discover where Genji is headed or where he spends the night, then how can he ensure that his affections trump the lure of other roaming eyes? Despite being slightly higher in rank than Genji, Tō no Chūjō recommends himself as an attendant whom Genji would do well to value and keep close..$^{37}$ Tō no Chūjō's complaint makes it seem as though he would be content with Koremitsu's job, gladly willing to shed his own precious rank for the chance to gad about as Genji's sidekick.

But "it made Genji feel bitter to be discovered like this," and the reproach he suffers here strains his alliance with Tō no Chūjō. ${ }^{38}$ This is because unlike the faithfully indentured Koremitsu, Tō no Chūjō is not beneath Genji. Therefore, Genji must cover any resentment with aplomb befitting his station; there can be no tantrum like there was with Yügao's death. Sore feelings nevertheless surface in a grievance-airing spat and then subside as the two men untangle wishes for affectionate proximity and romantic independence.

Fences typically figure as membranes that mediate and magnify scopic pleasure. Here, however, the tattered stretch of fence intimates a queer interval insofar as its porousness dilutes heterosexual desire. With this dilution comes Genji's "adhering to the shadows as he stood there hiding" (kage ni tsukite tachikakuretamaheba) as he tries and fails to gain the upper hand. ${ }^{39}$ The border's dissolution makes it tougher to discern which man holds sway, hence the erotic subtext percolating in the moonlight poems. The poetry puns on shifting placements: being together, turning our steps away, hiding, hunting, the unseen point at which the moon enters mountains. The homoerotic tenor of these movements issues from the frayed nook where the men reveal themselves. Genji and Tō no Chūjō emerge from the bushes with renewed mutual fondness:

Now feeling warmhearted and thus unable to part ways to visit the previously promised destinations they each had, they rode together in a single carriage along a path beneath a moon appealingly shrouded by clouds, blowing in unison on their flutes until they reached His Excellency's residence.

They had sent no herald to ride ahead of them, so they snuck in, changing from their disguises into proper dress cloaks in an unobserved corridor. Then, pretending innocence, as though they had just now arrived, they burst into piping away on their two flutes..$^{40}$ 
While the flimsy fence allows a woman to come between them, it by the same token lets the men enjoy closer contact. The concealed spot along Suetsumuhana's tattered fence provides a stretch of time and space in which to amend the men's rapport. This gap, conventionally disposed toward men's spying on women, instead hosts a renewal of male homosocial bonds.

Having outed their identities and aired their gripes, Genji and Tō no Chūjō can redouble their affection. Neither opts to leave the other's side for the sake of chasing women's hems. Instead, "unable to part ways . . . they rode together in a single carriage" (e yukiwakaretamahazu, hitotsu kuruma ni norite)..$^{41}$ This ride in the same carriage supplies welcome levity after the skulking and bickering. In part, mourning drives Genji into another man's carriage, once he finds that a fusty woman is less available than his male companion. Besides grieving Yūgao, Genji wants to abandon the burdens of propriety and precedent to enjoy a bit of spontaneous recreation with his male friend.

Yet Edith Sarra urges us to notice the intentionality this friend displays in dragging Genji back to Tō no Chūjōss natal home: the domesticated orbit of the Sanjō mansion, where the Minister of the Left, Tō no Chūjō's father and Genji's fatherin-law, resides. The deliberate swerve back to this location reads as a corrective of Genji's neglect of Aoi, Tō no Chūjō's sister. Thus the men's travel prefigures the type of maneuvers seen in the twelfth-century Taiki, where courtiers' homoerotic enjoyment is deployed in service of homosocial alliances secured through their daughters' or sisters' marriages. ${ }^{42}$

The carriage grants privacy after the double exposure of loitering outside and having one's clandestine visit divulged. Read against radiance that "bathes each village alike" (sato wakanu kage oba, literally "without division"), the men's new spatially enclosed encounter "beneath a moon appealingly shrouded by clouds" (tsuki okashiki hodo ni kumo kakuretaru michi no hodo) implies a less dominative optic. ${ }^{43}$ Discord wanes in these quarters. Whereas they prowled around before, the carriage's enclosure now lets them live out loud. They cut loose on flutes, the phallic rods proving the perfect instruments through which to express their bliss at reaching accord. ${ }^{44}$

Reentering the official confines of the Minister of the Left's Sanjō mansion compels the men to dial their revelry down momentarily, before the master of the manor and some female attendants join in a scene of domestic revelry. The ludic surges at the fence and carriage abate as hierarchies of rank and gender reassert themselves within the mansion's walls. Their behavior marks the space as more constrained than the moonlit copse or carriage. As they "steal in" (shinobi irite), unattended by any menials who would advertise their arrival, Genji and Tō no Chūjō must abandon their rustic outfits. They reassume the perfunctory guise of "innocence" (tsurenau) expected within this patriarch's purview. Yet more respectable need not mean authentic: the juxtaposition of these costume changes marks them as comparable masquerades. 
The primacy of the court cloak wavers once we consider how the men play after dark. Moreover, the very vastness of the mansion furnishes crannies for circumvention like "an unobserved corridor" (hitominu rau). ${ }^{45}$ As Kojima Shigekazu observes, Genji traffics in the trope of men needing to abase themselves for courtship, hiding and seeming shabby to secure intimacy with women. ${ }^{46}$ But this convention implies that no such requirement exists for intimacy with men, thus Genji's blithe undressing with Tō no Chūjō after they return from Suetsumuhana's fence, with barely any barrier between them.

Insistent desire for homosocial intimacy links divergent spaces-the tattered fence, the carriage, and the deserted gallery-allowing different kinds of closeness. The eroded fence tempts Genji with a better peek at the lady of the house, but the tract also lets a male admirer observe his movements from a comfortable distance. The carriage hosts the final stage of the men's tiff. After all the furtive stalking, gazing, and abrasive repartee, the two relax their guard in the carriage, allowing reconciliation through unabashed frolic on their flutes. Finally, the deserted gallery lets Genji and Tō no Chūjō dress in front of one another, hurriedly switching outfits to hide the romp enjoyed outside the palace gates. Along the arc of departure from the palace and return home to Sanjō, Tō no Chūjō and Genji run the gamut of emotions: curiosity, suspicion, dismay at being left behind, voyeuristic pleasure, anger, amusement, annoyance, and joy.

The "Suetsumuhana" chapter, whose ostensible linchpin is its titular female protagonist, in fact treats the woman and her wasting house as way stations along a more intricate elaboration of male homosocial attachments. Through touchstones like the tattered fence, the narrative foregrounds queer potentialities that fluctuate alongside prevailing patterns of conveying desire. While more than incidental to the plot, Suetsumuhana's presence becomes a medium through which Genji and Tō no Chūjō negotiate their fraught affection for each other. This mediation occurs in imaginative, textual, and spatial registers. For example, the lady's restraint unveils the imaginative space in which thoughts of bliss spill into homoerotic musing:

The young lords remembered those notes of the zither, their thoughts lingering pleasingly on how unusual that pitiable house had seemed. Tō no Chūjō even thought, How marvelous it would be for that quite enchantingly lovely lady, who'd likely spent all that time uncourted as the months and years piled up, to fall for him at first sight; he'd be so desperately lovesick that everyone would no doubt make a massive fuss, and his own feelings would likely make him a sloppy specimen. Halfway irritated, he worried about the conspicuous air Genji gave off like this: Is there any chance that guy would ever pass up such a perfect prospect?

After that, it seemed each of them was sending letters Suetsumuhana's way. Neither of them saw a reply, which bewildered and miffed them. She's really being too callous! Someone living in a place like that should certainly profess artfully what moves them by gauging their emotions from time to time, linking all the melancholy feelings they've known to the ephemeral impressions of flora or the sky. Her manner was solemn 
[omoshitotemo], but still, that she'd stayed buried in herself so much this way [ito kau amari umoretaramu] was obnoxious and unbecoming. Tō no Chūjō smoldered more on this score than Genji. ${ }^{47}$

Notice here that Tō no Chūjō's desperate lovesickness (imijiu kokorokurushiku ha) arguably matters less than the fact that "everyone would no doubt make a massive fuss" (hito ni mo motesawagaru bakari ya). The explosion of gossip carries the real force; heterosexual love counts little unless one's male rival musters reasons to resent it. What Tō no Chūjō actually relishes is the delicious thought of driving Genji mad.

Genji's caprice in taking lovers prompts Tō no Chūjō to imagine a joyful future with some woman he's never met. Rather than heterosexual courtship merely serving as a vehicle for homosocial intimacy, then, this fantasy shows how the prospect of a happy heterosexual future derives directly from men's desires to surpass one another. Getting the girl is not enough; Tō no Chūjō wants the world to know, so he can rub Genji's face in it. The fantasy's excess is telling. For indeed, it seems like the passion he dreams up subsists on Genji's recognition. Identification with Genji-as bosom friend, bitter rival, and even potential lover-suffuses Tō no Chūjö's consciousness such that the folly he provokes could easily refer to the risk of falling for Genji. Such a tremulous margin lets Tō no Chūjō meander into Genji's mind: "Is there any chance that guy would ever pass up such a perfect prospect?" 48

Putting himself in Genji's shoes gives Tō no Chūjō the boost he needs to pursue his reckless love; without Genji in mind, he'd lack the will. And yet,

Tō no Chūjō was quite irked thinking Suetsumuhana had snubbed him. Genji came to think it tiresome that he was facing such apathy in a situation for which he lacked any deep concern, nevertheless he figured that if that Tō no Chūjō was making overtures this way, she would likely yield to the person who kept wooing her by corresponding the most. The image of the smug face she'd no doubt make upon dismissing all notion of her original suitor proved keenly oppressive. ${ }^{49}$

This frustration prompts the anxious exchange of letters. Once again, Tō no Chūjōs desire to win Suetsumuhana stems from an investment in his comrade's response. His concern about her tendency to stay "buried in herself so much this way" (ito kau amari umoretaramu ha) extends from his own penchant for baring his soul to Genji, which he fears won't be mutual. The spatial metaphor of being "buried" or "shut up" refers both to the architectural impediments thwarting the men and to the lady's indifference. More than desiring entrance to her garden, however, Tō no Chūjō aspires to burrow into Genji's confidence. Love can be cruel, though, and Genji's own frustration at being rebuffed leads him to needle his colleague. Genji's nonchalance mimics the strange silence Tō no Chūjō received writing to Suetsumuhana. In this regard, both Genji and Suetsumuhana frustrate others by withholding. Their difference, though, hinges on Genji's willingness to mislead his friend to generate some tolerable response. Lacking answers from their primary 
target, who lies out of reach, the men turn to each other. Genji can't make the lady want him, so he savors his comrade's irritation instead.

This tactic implies a micropolitics of disclosure wherein emotional vulnerability becomes gendered and spatialized. Compelled to confide in Genji, Tō no Chūjō "inquires woefully" (to urehureba) about Genji's own luck on the same romantic score. $^{50}$ In sharing like this, Tō no Chūjō misrecognizes their status-based symmetry as assuring some inclination to confess insecurity reciprocally, much like he did in the "Rainy Night" conversations. But intimacy need not assure reciprocity, and those close to us can often scar us worst. In this case, Tō no Chūjō, still humming from an adventure where he and Genji rode merrily in a carriage "now feeling warmhearted" (amaete) and "blowing in unison on their flutes" (fue fukiawasete), mistakes Genji as a confidant and shares just enough to get hurt. ${ }^{51}$ In lieu of soothing words, Genji feigns indifference, lying that he "lacked any deep concern" about being rebuffed by Suetsumuhana. This slight nettles Tō no Chūjō. Even so, the underhanded gesture still grants Genji some candid emotional contactsomething withheld from him by the baffling lady in the house.

Genji exploits an artlessness in Tō no Chūjō that he helped bolster earlier that same night. However, things have changed since Yūgao's murder. Genji's sudden switch in demeanor with Tō no Chūjō-from open to closed-feigns toughness at his friend's expense. Tō no Chūjō's masochistic willingness to be vulnerable to Genji lets Genji regain the pride he yielded in the haunted house. His newest slight reads as a recuperative maneuver. Since Genji can't recover what manhood he lost the night the spirit attacked, he rehearses hurt homosocially to mend the damaged border of his self. His dig at Tō no Chūjō thus reads as a bit of compensatory violence designed to retrospectively disown the emasculating violation he felt cowering against Yūgao's cadaver.

Breathless from their spell of fluting, Tō no Chūjō doesn't realize the extent to which he's being played. He becomes a vehicle through which Genji repairs chinks in his own armor. As such, Genji's ploy at simulating distance speaks to how badly his fragile barricade was sundered. Where the murderous apparition proved elusive to the touch, Tō no Chūjō is well within reach. Ultimately, it is this proximity that lends credence to Genji's callous efforts at distancing his friend. In his quest to nurture a semblance of sovereignty, Genji milks homosocial intimacy, subtly dominating his companion to approximate a reparative remove.

\section{THE VICISSITUDES OF MELANCHOLIC COURTSHIP}

Competition with Tō no Chūjō lets Genji rebuild his heterosexual masculinity by enacting a hyperbolic style of sexual pursuit whose dramatic arc wends smoother than that of the Yūgao scenario. But that episode haunts Genji. Consequently, Genji yields to a cattiness toward Tō no Chūjō that kicks their relationship from carefree camaraderie back into frenemy mode. Homosocial competition between 
the two courtiers spurs redoubled efforts at heterosexual courtship-seasoned with misogyny. Genji's interest in the mysterious woman is already taxed by her inscrutable reserve. Peeved, he remarks at one point that "it seems she's neither thoughtful nor quick-witted" (rauraujiu, kadomekitaru kokoro ha naki nameri)..52 Given this fading fascination with Suetsumuhana, Genji's enthusiasm for her survives only insofar as Tō no Chūjō stokes it.

However, beside this oblique arousal sit other motivating factors: "Spring and summer passed while Genji suffered from his chronic malady and his heart stayed quite continually immersed in a grief hidden from the world" (warawayamahi wadurahitamahi, hito shirenu monoomohi no magiremo, ongokoro no ito manaki yau nite, harunatsu suginu)..$^{53}$ Coupled with his impregnation of his stepmother, Fujitsubo, Genji's failure to prevent Yūgao's death gnaws at him as he mourns secretly. This concealed loss tangles ties in his life. In Genji's connections with Tō no Chūjō and Suetsumuhana, we glimpse traces left by his lover's sudden death:

\footnotetext{
"Truly, how I would love to settle down here with someone heartrendingly lovely to fret over and adore; I could lose myself in that to distract myself from my forbidden heartache. What a waste that what one imagines for this dwelling veers from the demeanor of the lady living here, who has nothing to recommend her [omohuyaunaru sumika ni ahanu onarisama ha, torubeki katanashi]," Genji thought. "Is there anyone but me who'd esteem her more? How I crave someone with whom to engage in some run-of-the mill repartee [nadarakanaru hodo ni ahishirahamu hito mogana], even if our connection's not especially profound." 54
}

How might mourning's tenor infuse our reading of queer space? We could unpack what it means for it to be "a waste that what one imagines for this dwelling veers from the demeanor of the lady living here, who has nothing to recommend her," especially as it relates to Genji's ongoing rivalry with Tō no Chūjō, and interrogate the nature of that marginally utopic "imagined place" (omohu yau naru sumika).55 Suetsumuhana doesn't match the expected mental image, and Genji wants a smoother or "flatter" (i.e., less jaggedly challenging) interaction with her, as do her gentlewomen. Bemoaning Suetsumuhana's worthlessness, Genji helps us understand Tō no Chūjōs value in distracting Genji from lingering heartache. Here, Genji seems to briefly disregard Suetsumuhana to imagine the newly discovered Murasaki, whom he seized in the narrative's previous chapter to help distract him from the "forbidden heartache" (arumajiki monoomohi) he feels for Fujitsubo and to postpone mourning work for Yūgao.

Genji wishes not merely to have "someone heartrendingly lovely," but also to install them in this removed locale to keep them safely to himself. Although scholars traditionally assume Genji dotes on women here, the text's language leaves open other possibilities as the phrases "not especially profound" (ito fukakarazu to mo) and "craved someone with whom to engage smoothly in some run-of-the mill repartee" (nadarakanaru hodo ni ahishirahamu hito mogana) suggest that Tō no Chūjo or Koremitsu might even fit the bill-especially given Genji's shaky 
standards. ${ }^{56}$ The demonstrated range of Genji's heterosocial and homosocial relations to this point in the narrative sustains this ambiguity.

Genji's “immersion in a grief hidden from the world” over Yūgao's death presses him to expand his ties to the living. Heterosexual conquest supplies one arena in which to prove himself while mourning. Genji tries time and again to breach Suetsumuhana's defenses and colonize her overgrown terrain. This new adventure's setting offers enough resemblance to the residence in "Yūgao" to let Genji process an emasculating grief in his own time, grazing along this site's fringes. He even admits, "Unlike how this would play out normally in conventional society, I'm not after all that you-know-what; what I want to do is spend some time seated on that ramshackle veranda of hers. I feel like she's outright incomprehensible to me." ${ }^{57}$ Genji doesn't understand Suetsumuhana mainly because he doesn't care to. Still, her veranda might lend some time and space to surmount loss. The creaky veranda reminds Genji of the ruinous site where he lost Yùgao, albeit without its lethal threat. Thus, every swipe he takes at Suetsumuhana distances the galling memory of the night he fumbled his sword.

Tō no Chūjō is mobile and resilient enough to play the dependable surrogate. Like the spool tossed out of sight and then retrieved by the melancholic child in Freud's paradigmatic account of mourning, Tō no Chūjō serves as Genji's manipulable implement. By leaving Tō no Chūjō behind, only to encounter him again; chiding him as a prelude to sharing a melodious carriage ride with him; and coaxing confession only to pirouette and shut it down, Genji repeatedly casts and reels, rehearsing mastery over loss with the rhythm of unkind deeds.

Deliberate oscillation of closeness and distance enables an impression of stability and dominion to grow. Hence Genji can increasingly forsake those close to him without fear of the deprivation their withdrawal could create. This may be why lust matters less than wasting time at the veranda. Occupying time this way, within such a liminal space, unconsciously evokes the Yūgao debacle while allowing a reprieve from grief.

Genji's drive to score distant women and bully comrades mimes a repetition compulsion aimed at denying the disorienting immediacy of loss. Whatever shape his intimate relations take, the long moments Genji spends along ragged borders like Suetsumuhana's fence and veranda unseat the primacy of sex as a motive. Beyond sexual relations per se, vital here is the capacity to linger at a remove near enough to help him handle his hidden grief and rebuild his fractured self-regard.

\section{SUETSUMUHANA'S GROTESQUE DISPASSION}

We've seen how this melancholic exercise plays out in relation to Tō no Chūjō, who covets Genji's companionship and esteem. However, this intimate homosocial rapport contrasts sharply with Suetsumuhana's predilection: 
Despite feeling thoroughly reluctant, since she hadn't the slightest notion how to do something like talk to a person like this, Suetsumuhana went along with Taifu's coaxing this way, figuring, She probably has some means to work things out.

An old person resembling a wet nurse had by this time drowsily entered the gentlewomen's quarters to lie down. There were also two or three young women who were hectically dolling themselves up, feeling much eagerness to witness Genjis looks, renowned throughout society. Having changed into suitable clothing and spruced up, Suetsumuhana herself went out to meet him, without a speck of such enthusiasm [nani no kokorogesau mo nakute ohasu]..$^{8}$

Notice the strong comparison between old and young women here. Kokorogesau denotes gestures designed to curry favor or attract attention, especially those intended to make oneself attractive to a suitor. While not as blasé as the sleepy old wet nurse, Suetsumuhana nonetheless lacks her younger compatriots' exuberance in primping for Genji's arrival.

Removed from the center of court life, Suetsumuhana avoids its bustle of politics, fashion, and romantic intrigue. Having lost her father and thus his clout, too, she seems to stagnate in her aging estate, oblivious to trends directing the tastes of those closer to the action. This ignorance dates her, tarnishing her appeal:

Over an absurdly faded layer of licensed pink she added a dress gown blackened past any trace of its original hue, and for the outermost layer, a highly lustrous, fragrant coat of ebony sable pelts. Although dignified regalia in olden times, for a lady who was still young, such an outfit struck one as all too glaring and dreadfully outrageous in how ill-suited it was [nigenau odoroodoroshiki koto]. Nonetheless, indeed, one could see from the look of her face how much colder she'd likely be without these pelts, and Genji regarded her with pity. ${ }^{59}$

Here, the plural use of the color black underscores the protagonist's drab eccentricity, with the senses of vision, smell, and touch all referenced through the ponderous ensemble. Moreover, her outfit implies a grotesque and even deathly animality through the sable skins adorning her body. Genji pities Suetsumuhana for her criminally oblivious fashion sense, and her cluelessness unnerves him: "Even as he wondered, What on earth possessed me to discover what every bit of her looked like? She made such an extraordinarily strange sight that he just couldn't help staring at her." ${ }^{\circ 0}$ From Genji's perspective, the narrator tells us the following:

First, her seated height was unusually tall, making her look like she had an elongated back; Just as I thought! Genji's spirit was broken. Next up was the thing that appeared oh so acutely flawed: her nose. His eyes landed on it at once. It brought to mind that elephant the Bodhisattva Fugen rode. It was startlingly high and drawn out, the reddened tip drooping a bit to make it astoundingly abhorrent. Her complexion was white enough to shame snow, bluish even, and her forehead was unsurprisingly broad. While all the face below it seemed to extend for a disturbingly long way. She was gaunt, so acutely skinny as to seem skeletal, and one could even notice her achingly jutting shoulders through her robe. ${ }^{61}$ 
Suetsumuhana's body is distended as though she has been stretched across a wirethin armature; she is translucent, but daubed with gaudy patches. Her droopy nose makes her bestial-if not extraterrestrial. ${ }^{62}$ The "overgrown old house" permits such deformations with its slack borders and the cloistering it provides. Suetsumuhana's physicality assumes something of the engrossing blend of fragility and excess displayed by her estate.

If we align our assessment with Genji's perspective, then it is easy to focus on Suetsumuhana's repugnance and forget the lady's own satisfaction with her remoteness as well as her decided lack of enthusiasm for romantic rigmarole. Whatever desire male suitors feel toward her, Suetsumuhana's contented ignorance insulates her from the volatility of their whims. For Suetsumuhana to have "no speck of any such enthusiasm" (nan no kokorogesau mo nakute) toward the most earth-shatteringly handsome and talented man in the realm says everything. Her anomalous disinterest-which puzzles her women and Genji both-can be read as a kind of queer agnosticism that barely suits up for heterosexual courting.

In her physical and emotional distance from ideals of romance, Suetsumuhana sits askew of the heteronormative paradigm that captivates the people surrounding her: "'Please hurry out to him! Don't clam up: congeniality really counts!' they said, egging her on. Since she was of a mind not to refuse what people said, she spruced herself up more or less and scooched out. Genji faked as though he wasn't looking at her, gazing off outdoors, but he stole oddly numerous glances on the sly." ${ }^{63}$ Her women long to have lives life enriched by some shining prince. Therefore, they haul her out from the house's inner recesses, proffering her as available for a suitor, even as that front earns "oddly numerous glances on the sly" (shirime ha tadanarazu) from Genji.

Yet unlike her enraptured gentlewomen, Suetsumuhana concerns her days with other, less fetching objects and objectives. As Genji visits the veranda, Suetsumuhana doesn't leap to his summons. Instead, she turns her back to him, reluctant to change her queer but comfy pace. That she tidies herself only "more or less" (sasugani, also "with reservations") marks her ambivalence in a bid to humor her ladies and take one for the team. And she doesn't stop there:

"It would match my own sentiment much better if only you, the one lacking anyone to care for her, would forego your misgivings [yurushiki onkeshiki nareba] and grow fond of the man in the midst of courting you now. Your unyielding disposition is cold-hearted," Genji said, devising his exit excuse.

When the morning sun pierces ice hanging from eaves causing them to melt, why do these poor icicles hold out hope though frozen stiff?

Despite his poem, all she gave him was an "Mm," with a slight smile, and her wholly uncommunicative manner was so wretched that he up and left. ${ }^{64}$

Genji pleads with Suetsumuhana to admit him, but she freezes him out with her "unyielding disposition" (yurushi naki onkeshiki). ${ }^{65}$ Unlike Utsusemi, she's not 
playing kittenish. ${ }^{66}$ Not surprisingly, Genji perceives Suetsumuhana's unresponsive "Mm" (mumu) as an "abject failure" (itohoshikereba, also "wretched" or "pitiable"), denying him the entrance that he expects and-in his mind, at least-deserves. ${ }^{67}$ The response is not unintelligible, just vexingly elliptical. Such a blasé attitude and cryptic refusal of Genji's alpha male antics confuses and disappoints himand Suetsumuhana's ladies. Her comportment reads as queer here because of its orientation away from normative expectations for heterosexual romance. Like the warped proportions of her physical figure, her affective and rhetorical responses defy courtly common sense.

\section{LAMENTING UNTIMELY TEMPERAMENT}

This disinclination poses a problem that is as spatial as it is libidinal. For indeed, the frustration Genji, Tō no Chūjō, and Suetsumuhana's female intermediaries feel stems ultimately from her reluctance to be moved-physically or affectively. This reluctance simultaneously sparks and stifles suitors' desire. Moreover, such an indifferent posture-embodying its own brand of queer contentment-induces the go-between's sympathy for Genji: “Taifu mused, I'd love to flaunt Genji to someone who would appreciate him, but alas, there's no fame to be found here. What a poor fellow! But at least she could rest easy knowing that Suetsumuhana was conducting herself honorably and would likely not do anything reckless or too brazen for Genji to witness." 68

"No fame/recognition to be found here" (hae majiki watari wo) reverberates in multiple registers. It speaks to the literal manner in which Suetsumuhana's dilapidated residence disallows infiltrations sought by men like Genji, along with prototypical romance. Suetsumuhana's asexual stance precludes the style of consummation that most hope will result in an heir. The ramshackle site hence symbolizes not just a bastion of waning customs but a vacant womb (miya) as well.

At another level, the "here" implies a place situated at some remove from expected vectors of felicitous heterosexual transmission and patrilineal succession. Remember that Suetsumuhana is the "last and best loved daughter born to his highness of Hitachi," who is "living in sad circumstances now that her father [is] gone." ${ }^{9}$ This lack of any strong political paternal or maternal backing causes Suetsumuhana's "sad circumstances" (kokorobosokute nokoriwitaru). However, this lack also generates the spatiotemporal conditions under which a queer circumspection toward the motivating logic of compulsory heterosexual reproduction emerges.

Dowdy Suetsumuhana embodies a temporal lag and spatial displacement inhospitable to the fundamentalist bent of Heian marriage politics. "No fame to be found here" means there is no place for such a system of patriarchal inducements to settle now that the sponsoring father has left the building-physically, if not spiritually. With the symbolic figure's exit, Suetsumuhana's residence loses the 
guarantor of ascendancy suitors often seek. Yet this paternal loss also opens spaces that decenter. The Hitachi Prince's death disenfranchises his daughter, but it likewise displaces her from the cruel circuit of Heian courtship in which the unwed women of her retinue yearn to partake.

Unlike these restless ladies, Suetsumuhana is in no hurry to wed. This reluctance situates her beside a handful of female protagonists in Genji who refuse marriage. ${ }^{70}$ Her lackadaisical disposition matches the regressiveness coating her clothes, customs, calligraphy, and capacity to respond to courtship "without a speck of such enthusiasm." ${ }^{71}$ There are temporal repercussions to Suetsumuhana's disposition. Koike Seiji observes the deployment of three uncommon narrative devices in "Suetsumuhana," all of which, I would argue, characterize Suetsumuhana's queer relation to standard linear time. The first two are "redundant or duplicate time" (chōfuku suru jikan) and "flashback technique" (kattobakku no gihō). ${ }^{22}$ These arise because her lack of commitment to participating in the prevailing temporal frame provokes protagonists to renarrate her predicament from alternate angles as they try to make her shape up. But she frustrates these attempts, stuttering time's passage. The third temporal device "Suetsumuhana" stresses is what Koike calls "blank time" (kühaku no jikan). ${ }^{73}$ This is represented most clearly in Suetsumuhana's comically blasé comportment toward Genji. Her "mms" and abject failure to reply drive Genji away. Suetsumuhana's lack of anticipation produces blank time, where the reader expects time to pass, but it doesn't, and narration of active events is scarce. Hence readers are placed in a position akin to that of her ladies-in-waiting. This untimely bearing syncopates courtship's narration and goads Suetsumuhana's gentlewomen to fill her empty hours with their anxious labor.

Fatherless, Suetsumuhana suffers (or enjoys?) a cushioned exile from the near-mandatory mores obeyed by ladies of her station. Whatever dispossession this brings registers as lamentable in the limited perspective of those so stuck within that matrix that they must view Suetsumuhana as pitiably alien, as "no footprint broke the vast, empty, and chillingly lonely expanse" of her grounds. ${ }^{74}$ Genji explains that "this interminable distance your heart harbors toward me is so very wounding" (tsukisenu ongokoro no hedate koso, warinakere)..$^{75}$ Suetsumuhana maintains emotional distance even on granting her suitor greater spatial access. Her discretion is an obsolete disposition that smacks of a lapsed style and era. Her propensity to reside so passively and passionlessly in such environs places Suetsumuhana outside the perimeter of their comprehension as anything but laughably pathetic.

Nevertheless, we would do well to understand her lapses as situating her beyond the manic presentism of heteronormative compulsions to be courted, wed, and impregnated (not necessarily in that order), and ideally to mother female children that would be serviceable to courtiers of Genji's trajectory. In being so irredeemably behind the times-inoculated against the flickers of anticipation felt by her attendants-Suetsumuhana unwittingly exempts herself from a lifestyle of 
jumping at callers and rushing to write replies designed to continually kindle the sexual interest or approval of men and women alike. As such, she is woefully heedless of courtship's conventions for correspondence:

Prodded by the gaggle of voices around her, Suetsumuhana wrote out her poem on lavender paper from so many years past that age had drained its color to ash gray; her characters were predictably crisp and sturdy [moji tsuyau], following an archaic style, with the tops and tails of her columns evenly aligned [kamishimo hitoshiku]. It wasn't worth looking at, and Genji put it down. It was awful for him to wonder what she thought of him. ${ }^{76}$

Her glyphs' robustness reflects a bygone sensibility and a rectitude garnered from an enduring paternal influence. Similarly, the even alignment of her columns' heights means she eschews the variable placement of "strewn script" (chirashigaki), whose stylishly scattered lines convey a savvy she lacks. Here, the disquiet Genji feels (omohiyaru mo yasukarazu) could stem from his disgust for Suetsumuhana's dated calligraphic style with its unambiguous evenness and unnerving encapsulation of stubborn anachronism in handwritten form. Even as Genji deems her unfit, the indelible stoicism of her script makes him fretful of her ability to appraise him, too.

Those around her view Suetsumuhana as hopeless; she disabuses others of their aspirations. She garners such concern from her gentlewomen and is so demeaned by the narrator because she refuses to play the game to which everyone else has committed themselves. Yet the qualities that disgust Genji and mark her as hopeless-like the startling equipoise of her writing-suggest that the very rubric of appraisal according to which she is judged prizes harsh asymmetries. The evenhanded lack of pretense Suetsumuhana's obsolete script exudes calls into question the crooked regime under which her legibility and value are appraised.

When we register the exasperation of Genji or these attending women, we encounter Suetsumuhana as a limit case for the coveted inequities of Heian courtship. For Genji, lightly refused on the balcony, Suetsumuhana's "indecision is tortuously harsh" (tamadasuki kurushi).77 Her awkward silence proves so illegible and distressing to those around her that "a sprightly youngster named Jijū, a daughter of Suetsumuhana's wet nurse, felt so anxious and mortified [ito kokoromotonau, katahara itashi] that she drew close to Her Highness and answered."78 In her fumbling nonchalance, Suetsumuhana lets other women remedy what they contend are her shortcomings. She lets young Jijü "draw close to her" (sashi yorite) to fill the void and rescue Genji's failing courtship. In doing so, she allows Jijū to sample slivers of the life the young woman yearns to taste, the same life Suetsumuhana turns her jutting back to.

For those anxious women encircling her, Suetsumuhana's backwardness takes a heavy toll. We see this when Genji's visit triggers an outpouring of shame and effort:

Taifu felt so awful for Suetsumuhana that she feigned ignorance and fled to her own room. These young gentlewomen, as one might expect, given the wide renown of 
his incomparable good looks, excused Genji's transgression and couldn't make some formidable protest bemoaning it, although it was quite unexpectedly sudden, and they worried that their mistress totally lacked the mindset needed for meeting men.

Suetsumuhana herself was wholly lost in a mortified daze, as though someone else, with nothing beyond her ashamed apprehension [tada ware ni mo arazu, hadukashiku tsutsumashiki yori hoka no koto mata nakereba]. Genji thus found this instance, unlike other moments, especially moving because she remained unversed in the world's ways and seemed to need someone to care for her. Even so, he found her clueless demeanor somehow quite pitiable. What about her could ever have captivated him? ${ }^{\text {?9 }}$

Genji's sudden entrance to the inner quarters shocks the women: "How awful of him! And he promised he wouldn't!" 80 Harsh phrasing in the original suggests that Genji's entrance wounds Suetsumuhana with a stunning shame; with his incursion, she contracts like a virus a strain of shame she didn't exhibit before, albeit one less intense than the jittery breed the women normally manifest. Yet Genji's brash encroachment seems to embarrass the women less than does their indelible association with Suetsumuhana. As Suetsumuhana's stock plummets, go-betweens like Taifu fear damage to their own reputations and spring to action like antibodies, lest the failings of their mistress ripple out to taint them, too.

The architectural contours of the women's quarters allow for the women's discomfiting identification with their mistress: their lack of physical distance from Suetsumuhana makes them susceptible to scathing embarrassment. For example, when Suetsumuhana ultimately sends Genji "an unforgivably sheenless and long outmoded light red [Chinese] dress cloak whose inner and outer colors were the same, making every inch of it strike one as utterly uninspiring, Taifu's face reddened [omote akamite] as she watched on." ${ }^{81}$ Having been tasked with delivering the awful Chinese robe, Taifu must touch it, announce it, and present it, even as she aches to disown the horrid cloak: "I can't fathom how you could possibly view what's inside this without feeling pangs of awkwardness" (kataharaitaku omohitamahezaramu). ${ }^{82}$ That she is the servant means she is the one who must "[undo] its cloth wrapping" (tsutsumi ni .. oshiidetari), opening the box to let her very pores be saturated by the shameful robe. ${ }^{83}$

Confidants like Jijù quell their mortification by answering in lieu of their fumbling lady: "Good heavens, [Genji] groaned to himself, what an awful poem! This must be the best she can do on her own-I suppose Jijū is the scholar who usually retouches her poems and guides her brush." ${ }^{84}$ Suetsumuhana's spectacular incompetence lets female proxies take her enviable place as Genji's love interest. Her concealment behind shutters and folding screens lets her serve as the vehicle through which eager women enact romantic aspirations and express their lust.

This trope of gentlewomen interceding and questioning their lady's romantic competence or even sanity for not making herself more available to the highranking suitor appears elsewhere in Genji. For example, Ukifune's attendants 
worry that the young beauty is wasting her natural gifts by not capitalizing on the male attention being showered on her. Suffering reduced circumstances and removed from amorous intrigues, they seem to need another woman's romantic fate to latch onto and believe in. In their ostensibly compassionate concern, the nuns caring for Ukifune pressure her to answer her suitors. As Margaret Childs explains, they are "aghast at [her] refusal to reply"; they "argue that her rudeness reflects on them and resort to questioning her sanity to explain her silence." ${ }_{5}$ Similarly, Suetsumuhana's women overidentify with her as participants invested in what Childs calls "coercive courtship."

The nature of this coercion, we should remember, entailed physical as well as psychological dimensions conditioned by the larger edifice of Heian patriarchal domination. As Childs notes, "Women of high birth, themselves badgered and bribed by the men pursuing their mistresses, often aided and abetted male suitors, most notoriously by secretly allowing them access to their mistress' bedrooms. They also echoed men's reproaches that it was cruel for a woman to reject a man." 86 The violence suffered by serving women at the hands of rapacious suitors (and those suitors' own anxious servants) metastasized into a mesh of microaggressions arrayed to sap their mistress' dissent. We should not interpret the way the serving women fall in line and "echo men's reproaches" as based in simple envy. Rather, we should acknowledge that the boundaries of self-interest can blur when your back's against the wall night in and night out. Operating within the Heian courtship apparatus, these women stand to gain both identificatory pleasure as intermediaries close to the romantic action and also some measure of relief from having momentarily sated the pack of suitors pawing at the shutters. Moreover, by selling out their mistress, the female attendants might moreover hope to earn some degree of socioeconomic reprieve from poverty for themselves.

As the residence's central occupant, who nonetheless maintains only a peripheral concern or wherewithal for the proper business of courtship's rituals, Suetsumuhana skirts social duty. Unwittingly, this clears room for other women to flirt on her behalf. Consequently, her obliviousness to the nuances of courtship greases the wheels of the Heian machine. Insofar as her uninterested ineptitude both stokes anxiety and makes way for more capable ladies to simulate her voice and take charge, Suetsumuhana's queer disposition obliquely fuels a regime of heterosexual relations she has neither the interest nor the skill to support.

That Genji finds Suetsumuhana's “comportment peculiar and somehow pathetic" attests to her insufferable queerness. She earns pity for not being as competently or energetically interested in men as her peers. Halfhearted at best, Suetsumuhana's dismal efforts at male-female courtship mark her as impenetrably queer in Genji's eyes: "He kept up a stream of pleasantries, bantering or serious, but nothing worked. In frustration before this evidence that she must be odd in some way [samagahari] or her feeling engaged elsewhere [omohukata koto ni monoshitamahu hito ni ya], he gently slid the panel open and entered." ${ }^{87}$ Suetsumuhana's 
performance in courtship is so abysmal that Genji cannot help but understand her as being abnormal. Genji's narcissism opposes Suetsumuhana's composure, preventing him from recognizing her reluctance as legitimate.

Given the liability Suetsumuhana poses for her female attendants and the time Genji wastes in trying to court her, the question, "What about her could possibly have attracted him?" rings out. To venture an answer, we must look not just at Suetsumuhana's characterization but also at the way her failings, transpiring at behavioral and architectural levels, coax Genji closer to his bosom buddy, unlocking a space for attraction askew of routine courtship:

Groaning, [Genji] took his leave late in the night. . . . He stole away very quietly indeed.

He returned to Nijō and lay down to brood on and on over life's endless frustrations and to lament that anyone of this Princess's not inconsiderable standing should have so little to offer.

These miseries were still whirling through his head when the Secretary Captain [Tō no Chūjō] arrived. "You are certainly sleeping late!" he said. "I am sure there must be a reason."

Genji arose. "I was overindulging in the luxury of sleeping alone. You have come from the palace?"

"Yes, I was there just now, his friend answered breathlessly. "Today is the day when the musicians and dancers are to be chosen for His Majesty's progress to the Suzaku Palace. I heard about it last night, and I am on my way now to inform His Excellency. I shall have to go straight back."

"Well, then I shall go with you." Genji had them both served a morning meal, after which they got into the same carriage, though the other one followed it.

"You still look rather sleepy," the Captain observed reprovingly, and he added with some rancor, "You have a good deal to hide."

... Remembering with a pang of guilt that he owed [Suetsumuhana] at least a letter, he finally sent one that evening. What with the weather having turned wet and his not really being free to leave, he may well have wanted nothing to do with any "sweet shelter from the rain."

At Her Highness's, Taifu felt very sorry indeed once the time to expect a letter had passed. She herself remained deeply ashamed. ${ }^{88}$

The "Suetsumuhana" chapter demonstrates the performative and often ludicrous character of Heian courtship. In their failure, Genji's and Tō no Chūjō's solicitations highlight a fallibility embedded in the larger Heian system within which courtship operates. In suspending these overtures, Suetsumuhana triggers a romantic disarray whose queerness stems more from the disruption of heterosexual romance than from any homoeroticism marking Genji's relationship with Tō no Chūjō.

Tō no Chūjō gains from his contrast with Suetsumuhana. Before, Genji was frustrated by his friend's nosy neediness. Now, unable to land the woman he wanted, Genji permits Tō no Chūjō’s company again. As though magically granting Genji's wish, Tō no Chūjō rushes in right as his sulky friend "lay down to 
brood." Although the text makes no mention of intercourse, the sexual frustration Genji feels, his recumbent position, and Tō no Chūjō's panting, probing questions all sketch edges of its silhouette. After sharing their morning meal together, the men again share the same carriage, much as they did after bickering in the hedges, despite the plain availability of two vehicles. The empty carriage underscores the absence of the female lover originally sought, a reminder that neither man need ever fear the "luxury of sleeping alone."

That Tō no Chūjō has to go "straight back" implies undeviating haste; that he speaks to Genji "breathlessly" carries erotic implications even as Tō no Chūjōs exhaustion gives Genji something he might identify with as he broods. By his own admission, Genji wants no "shelter from the rain" because he would rather not have the chilly bed of Suetsumuhana's residence that goes with it. Genji's reluctance to send his awkward prey a letter stems from an ongoing frustration that Tō no Chūjōs welcome visit only galvanizes. His invitation to return to the palace seems preferable even despite the shade cast by the phrase "with some rancor" (to, togame idetsutsu), as Genji tries to hide his exploits from his stewing companion. Better to endure this intimate companion's barbs than another night stranded on some oddball's veranda. With Tō no Chūjō's breathless arrival in the middle of Genji's brooding defeat, Taifu's shameful worry that there is "no fame to be found here" (hae arumajiki watari wo) connotes homoerotic potential. Whatever heterosexual "something" might have blossomed between Suetsumuhana and Genji has been compromised. But Suetsumuhana has queered the playbook by baffling her suitors and leaving them lonely and exasperated. Consequently, the increased homoeroticism later in the chapter stems from the contingency her awkward actions forces them to confront. Thus Genji's interest in a rival with whom he has shared the bushes and a buoyant carriage signifies a bid for consolation. This homosocial bond outshines prospects with the dowdy misfit because its reliable eroticism reassures against her queerness.

\section{HETEROSEXUAL PANIC AND SHAME'S \\ SYSTEMIC FUNCTION}

Rather than spotlight Suetsumuhana's failings, we might wonder why everyone becomes so mortified on her behalf. She becomes a locus for panic about the potential breakdown of optimal heterosexual romance. Her clueless celibacy undoes the natural order of things, even exposing its deficiency, like the "absurdly faded layer of licensed pink" (yurushiiro no warinau uhajiramitaru hitokasane) she wears. ${ }^{89}$ For Suetsumuhana to engage her feelings elsewhere disappoints the protagonists (and narrator). Yet it also unlatches a space wherein those most captivated by heterosexual intrigue can redouble their investments in its social workings.

In response to this queer disengagement from heterosexual courtship, Genji and Suetsumuhana's gentlewomen venture to save her by prying her out of her 
shell, bringing her to her senses, and making her over. The vicarious shame swirling around her adjoins Genji's suppression of shame, on the one hand, and the investment in paradigmatic romance he shares with Suetsumuhana's anxious ladies, on the other. However impracticable it proves, this farcical courtship nonetheless remedies the violent humiliation Genji suffered in losing Yügao. $\mathrm{He}$ could compensate financially for his prior emasculation as potential patron of this household, which would also hold incentives for its impoverished gentlewomen.

In discussing the mechanics of identification and group psychology, Freud writes that features of the herd instinct include "the weakness of intellectual ability, the lack of emotional restraint, the incapacity for moderation and delay, the inclination to exceed every limit in the expression of emotion and to work it off completely in the form of action." ${ }^{\circ \circ}$ The gentlewomen's manic energy, outpouring of shame, and insistence on urgently rectifying Suetsumuhana's gaffes fit this description. Freud goes on to explain that among the "primary" instincts "of selfpreservation, of nutrition, of sex, and of the herd . . . the last often comes into opposition with the others." ${ }^{\text {"91 }}$ Self-preservation, sex, and herd instinct actually go together in this case, insofar as the Heian marriage system enforces an extensive faith in officially recognized sexual reproduction with men of high rank as the best bet for status and comfort, if not survival. Thus the shame Suetsumuhana's compatriots feel and the guilt they force on her arises from a sense of duty to their families, themselves, and to the system in which they have invested so much of themselves, not to mention their dreams of a brighter future. Accordingly, from their perspective, Suetsumuhana needs to get it together and pucker up.

We watch surrounding women grow envious of Suetsumuhana's (undeserved?) capacity to garner Genji's interest. When we read that Suetsumuhana "was gaunt, so acutely skinny as to seem skeletal" (ito woshige ni sarabohite), and that Genji "could even notice her achingly jutting shoulders through her robe," it seems like a literal symptom of her indigence, morbidity, and outworn sensibilities. However, this corporeality also registers symptoms of the wounding system all these protagonists inhabit. ${ }^{92}$ Like a nail that must be hammered flat, Suetsumuhana is goaded back into the fold of normative courtship's hope-mongering. Shame disables the majority's desire to self-examine so they can discipline the misfit instead.

Mixed with pity, Genji's experiences of losing his mother and Yügao become underlying factors in his projection of a pathological awkwardness onto Suetsumuhana. The surrounding protagonists' and narrator's sprint to a paranoid reading of her disinterest as loathsome and unsound reflects deeper fears. Specifically, their excitement and shame index the precarious nature of the sexualeconomic regime under which they subsist. Therefore, reluctance to participate fully in that regime must be forcibly designated Suetsumuhana's own personal, pathological shortcoming.

On this point, Judith Butler's notion of the law as "a prohibition that generates sexuality or, at least, compels its directionality" helps us understand the shape 
and force of shame aimed at Suetsumuhana as issuing from a compulsion to normalize. ${ }^{93}$ For Butler, "the 'performative' dimension of construction is precisely the forced reiteration of norms," and constraint represents "the very condition of performativity. . . . Constraint is not necessarily that which sets a limit to performativity; constraint is, rather, that which impels and sustains performativity." ${ }^{4}$ This insight helps us understand courtship in Genji as being especially invested in an iterability and ritualized constraint. Suetsumuhana is ostracized so theatrically because her spatiotemporal and affective orientations threaten unspoken injunctions to maintain the directionality, speed, and temperature of Heian social intercourse. Her composure impugns that system's legitimacy. She manifests as grimy and misshapen to serve as the abject figure through which others ditch their misgivings and buttress their own frail faith in a cruel romantic regime. They fight to normalize her romantic interactions because the queer style of celibacy she practices undercuts their belief in the rumored virtues of Heian courtship.

Suetsumuhana's queerness activates a redoubling of investment in the most reductive narratives of romance available. So we shouldn't be surprised when the narrator self-consciously highlights the generic conventionality of the protagonist's ugliness: "It may seem mean-spirited to comment even on the various clothing she was wearing, but even in the ancient tales it appears they began by discussing the person's costume." 95 The ruthless depiction that accompanies this qualification trades on the pleasure accompanying the reading audience's disidentification with such a weirdo. The incident's narration helps us understand how desire circulates both within and around Genji. For instance, how should we interpret the desire of female Heian readers to witness Suetsumuhana's shaming unfold? And not just unfold, but surface through grotesque physicality that marks her as hopeless or unsympathetic?

Theorizing the relation between the rhetoric of embarrassment and the spatial structures within which Suetsumuhana's protagonists maneuver, we observe that Suetsumuhana's otherness strikes several characters as alienating and shameinducing because it is too close for comfort. Its peculiarity infects their own prospects for social mobility. Here, we need to take into account the propensity of built-space to recruit from mid-ranking gentlewomen the hope and vicarious engrossment that fuels both sexual and readerly interest.

Suetsumuhana's house is a shameful place. Ragged fences and shabby gates notwithstanding, her residence hosts shame in all its vitalizing mayhem. For all their groaning, the protagonists need the shame Suetsumuhana anchors: their removal from the lustrous avenues of court life makes shame a welcome guest when no one else will visit. Blushing still counts as lowkey arousal. Wanting to help Suetsumuhana "succeed" in a pursuit she herself is ambivalent about helps inoculate oneself against the taint of her queer affect. It seems prudent to dispel doubts about the broader system by ridiculing her ineptitude in the realm of proper society. Suetsumuhana's incessant failures make room for intermediaries like Jijū and Taifu 
to take the stage intermittently and smooth out romantic relations their clueless mistress botches.

Drama builds as paradigmatic assumptions of heterosexual romance falter. Responding to Genji's incomparable appeal, these women spring into action as lubricating agents within the Heian matrimonial machine. These women's shame owes its intensity to the ideological dominance of Heian marriage politics as an institution beyond which little alternative can be imagined. Hence the primping and scooting to glimpse Genji's approach stems from an endemic inability to see past scented letters and would-be husbands. Granted, this activity might help the women's families economically, so we shouldn't malign them as insensible or self-serving. Nevertheless, consider how drastically a macro-level system induces micropolitical machinations.

Frantic group effort claws Suetsumuhana back into Heian patriarchy's grid. Indeed, her dingy clothes, tall back, bony shoulders, and stodgy writing all accent an angular disposition that warps accustomed styles of desiring and its outcomes. Unlike the flowing cursive executed by more stylish protagonists like Genji or Oborozukiyo, Suetsumuhana's staid, separated characters exhibit too much balance to entice Genji's eyes. That stiff regularity denotes a difficult seduction: despite her aberrance, her script implies that she sits resolutely, if vexingly, in line. Female surrogates must therefore enter the game to pinch-hit for their mistress, filling in the galling blanks left in her judicious, dispassionate columns.

The chapter elaborates a symbiotic relation between the dilapidated house, the disaffected queer mistress, and the regiment of anxious intermediaries primed to make this courtship system function at all costs. If the beams and lattice shutters, aisles and veranda railings supply the skeleton, then these serving women lend the marrow. Within this organistic institution, Suetsumuhana's queer withdrawal presses into action a teeming network of worry designed to metabolize shame for the benefit of Heian matrimony. They rally to reinscribe what Suetsumuhana lets crumble. Shame's fluctuation supplies a vital force of social cohesion among women of similar rank in the estate. At the same time, this microcosmic cohesion references a wider system of patriarchal organization dependent on the perpetuation of gendered class hierarchies in which women reproduce for the sake of gaining access to higher status and better lives.

\section{ANTICIPATION, FASCINATION, AND CROOKED REDEMPTIONS}

Genji's arrival glints with the promise of deliverance from suffocating boredom. The prospect of sex with Genji becomes the "thing" (mono) around which "stories are spoken" (katari). Hence monogatari names a paratactic discourse associated with sexual contact even as such talking only grazes the act. The primping gentlewomen's machinations attempt to yield a successful sexual, if not 
marital, union of Genji with Suetsumuhana, even as she herself occupies the sidelines, lukewarm.

Suetsumuhana's queerness - that erotic agnosticism marked by an absence of attraction toward the promise of heterosexual coupling-introduces a destabilizing risk into the Heian social system. ${ }^{96}$ Indeed, this threat must be neutralized precisely because Suetsumuhana herself is so incorrigibly neutral. With her matted pelts, stiffly balanced script, and lack of even a "flicker of any such anticipation," Suetsumuhana threatens to infect the regime at large with the same corrosive neglect for prevailing social practices that pervades her lapsed estate.

The urgency displayed by residents of Suetsumuhana's house doing damage control derives from the dearth of visible alternatives to this patriarchal Heian framework. They fret so much because little else makes sense in so familiar and pleasurable a way. Ultimately, what this scenario underscores is the social utility of this woman's queerness, the valuable function it serves within a system focused most intently on reproducing itself. The giddy pomp of courtship highlights the need to reinforce the routines shaken by Suetsumuhana's inclination to comport herself otherwise. Her queer leaning thus becomes serviceable to this larger apparatus. To the extent that it spurs compensatory activities that pick up the slack, the system is able to incorporate Suetsumuhana's queer affect as a stimulus for maintaining homosocial bonds among mid-ranking women, on the one hand, and the institution of Heian marriage those bonds undergird, on the other.

To call the noncommittal Suetsumuhana's bearing a "refusal" ascribes it a deliberateness that doesn't fit. Her premodern Japanese example foregrounds limitations of queer theory steeped in a modern, Western, adamantly antinormative stance. Rajyashree Pandey's critique of modern conceptions of agency premised "on the assumption that behind every act there is the presence of an autonomous individual, who has the innate desire to strike out against the norms of her society," resonates here. ${ }^{97}$ As she recommends, if we "were to let go of this anachronistic assumption, and were to decouple agency from liberal thought," that might "open up a space for imagining alternate readings of agency that do not presuppose the validity and universality of conceptions and norms based on modern notions of autonomy and freedom." ${ }^{98}$ I read as queer the text's opening of such a space for imagining otherwise through Suetsumuhana.

Her posture entails a habit of hesitation befitting her medial position between the desires of Genji and those of her female retinue. While this puts her at odds with feminist or queer readings that prize erotic indulgence or denial as patent examples of agency and resistance, Suetsumuhana's half-hearted indeterminacy places her at a proximate remove from either gung-ho lust or wholehearted refusal. This interval poses a somewhat unfashionable question of celibacy, which Benjamin Kahan understands as "an organization of pleasure rather than a failure, renunciation, or even ascesis of pleasure." ${ }^{99}$ Indeed, Kahan's discussion of celibacy's stepchild status within sex-positive ideals of feminist and queer activism and 
theory highlights blind spots in our capacity to recognize less active or less insistent dispositions. We might learn to discern and value figures who are stridently celibate or half-heartedly sexual.

Suetsumuhana flirts with such potential disregard. In contrast to behavior of female Genji protagonists like Onna San no Miya or Ukifune, whose hair-cutting flights to Buddhist monasticism or nonparticipation in written correspondence with suitors read more swiftly as oppositional, Suetsumuhana's attitude might be more accurately described as a lenient unwillingness to follow suit, and Suetsumuhana herself might be seen as someone whose illegible pleasures must be diagnosed as dysfunctional and promptly redressed. Although this ascription, to say nothing of the narrator's tone, paints Suetsumuhana pejoratively, a notion of dysfunction isn't entirely off mark.

For after all, the rhetoric of shame and the exasperated scurrying we hear tell of does in fact respond to a risk of societal malfunction raised by Suetsumuhana's dispassion. These affects and concerted actions surface to discipline or quarantine Suetsumuhana's queerness so that it doesn't impair operation of the larger apparatus to which Genji and the women bear allegiance. Hence the rally to smooth her edges, to make her more legible and more desirable within a network of courtly romance whose continual reinscription of generic ideals conditions intertextual and interpersonal affiliations alike. In this light, the narrator's self-conscious reference to such a scenario's fictionality-its "monogatari-ness"-accents links to a broader fictional lineage while Suetsumuhana's incapacity to assimilate underscores that genre's discontinuity. To keep her hidden and forge calligraphic couplets on her behalf is to disavow the simmering dysfunction stoking the Heian marriage machine.

An enigmatic figure, Suetsumuhana elicits paranoid fascination from both Genji and ladies of her own house. Flanked by these two contingents, Suetsumuhana becomes subject to their interlocked narcissisms. Their redemptive effort takes place as a disciplinary-if not persecutory-project to accelerate and straighten Suetsumuhana's slow, crooked ways. Suetsumuhana is perceived as epitomizing deficiency. Her ways are not timely enough, sensual enough, engrossing enough, fashionable enough, or serviceable enough to guarantee social reproduction in its most efficient guise. As such, the Heian system strains to draw her back into circulation as a properly functioning subject within its economy of enforcement-but fails to do so fully.

\footnotetext{
CONCLUSION: SUETSUMUHANA'S LAPSES AND THE COMPULSION TO CURB QUEER TIME
}

Suetsumuhana's gentlewomen worry that she has no future. Her timeworn ways and lack of anticipation toward Genji's advances place her askew of a dominant vector of incessant forward movement. This entrenched trajectory proves merciless 
in its mandate for efficiency; it's embodied by the narrator's derision, Genji's sullen irritation, and the shame felt vicariously by Suetsumuhana's entourage. All the waiting Suetsumuhana performs - and, in her own retiring manner, demandsdisturbs such a network of relations.

The arc of "Suetsumuhana" demonstrates how loss-of love or opportunity, actual or imagined-elicits intimacy between courtiers and women fearful of being continually or irrevocably dispossessed. ${ }^{100}$ Suetsumuhana's loss of her father makes her both vulnerable and valuable as inklings of her own dispossession surface. Without paternal support, she lacks a considerable measure of protection, but she also controls an estate she might not were her father still alive. Moreover, as women's rights to property are curtailed over the course of the Heian period, courtiers encroach to inspect candidates for plunder. Therefore, Genji and Tō no Chūjō's rivalry for Suetsumuhana's affections cannot be divorced from her queer relationship to property and paternal inheritance.

Tō no Chūjō couldn't care less about her, ultimately; he's just courting her to keep Genji close and attentive. However, for Genji, barred from assuming full official privilege as an emperor's rightful heir, Suetsumuhana seems promising as a romantic conquest prone to grant him access to territory that might offset the maternal and material losses haunting him. Symbolically at least, the conquest of such an orphaned estate could help soothe his existential sense of dispossession.

But Suetsumuhana evades this conquest even as she fumbles through courtship's protocols. If, according to Judith Halberstam, a "queer way of life" is characterized in part by "alternative methods of alliance," then Suetsumuhana's queerness might extend from an unremarked on mode of familial attachment. ${ }^{101}$ Namely, Suetsumuhana allies herself with the residual presence of her long-dead father: his written hand, his poetic diction, his moldering clothes. The awkward daughter is unwittingly yet indelibly steeped in paternal precedents that impede her capacity to court Genji successfully. Her attitude diverges from the "willfully eccentric modes of being" Halberstam advocates. ${ }^{102}$ Suetsumuhana maintains an unwillfulindeed unconscious-yet formidable alliance to perished forms. This eccentric investment in obsolescence roots her belatedness, her much-bemoaned incompetence, and her negligible allegiance to the headlong rush of aristocratic romance.

We can understand Suetsumuhana's attachment to the past in nostalgic or melancholic terms. She wants to keep the material possessions and immaterial sensibilities bequeathed by her father. For a daughter like Suetsumuhana, the expectation is for her to find backing to replace that lost on her father's death-as soon as possible, preferably. Her unwillingness to hurry worries her women as her property rots and she threatens to die a spinster, dragging them with her. Ultimately, hostility so surrounds Suetsumuhana because her peculiar stance nudges those around her to question the naturalized sociality they love to take for granted. Her queer lag disrupts the widespread drive to outstrip extinction through rituals aimed at social reproduction. But property and pregnancy barely matter to such 
an outlier. And this is what spurs cravings to censure and reform her: the queer way her comportment questions how intimacy should transpire.

Genji's fictional portrayal of the affair with Suetsumuhana seems designed to earn laughs from Heian readers who knew all too well just how prone to malfunction and tampering the whole courtship enterprise was. For many of these heavy investors in the Heian court, Suetsumuhana's gaffes likely brought pleasure, since readers identified more agreeably with the scrambling gentlewomen or even Genji than the irredeemable basket case floundering in the dilapidated mansion. Her sheer abjection made it easy to disidentify through humor and scorn, much in the manner the chapter's protagonists themselves perform. And yet the recurrent trope of spatial porosity and the flood of infectious shame suggest that such humor, scorn, and schemes to solve or discipline Suetsumuhana's aberrance derive from an abiding unease about its capacity to transform the very nature of Heian sociality.

Despite the army mobilized to contain her energies, the dimensions of Suetsumuhana's personhood-like the distended proportions of her very body-momentarily evade delineation. Much paranoia is unleashed toward Suetsumuhana's grotesque obsolescence-akin to the "horror" of MerleauPonty's formulation. It is therefore not merely her failed courtship that marks Suetsumuhana as queer, in the sense that it demonstrates disinterest in ideals of heterosexual coupling. More significantly, it is her noncommittal posture toward the trajectory all her ladies and suitors covet. Her singular lack of even a "flicker of any such anticipation" denotes a queer commitment to the pleasure of pastimes that are as absorbing as they are unconcerned with the prospect of reproductive futurity. In her shabby belatedness, Suetsumuhana tarries along, incapable of appreciating the urgency-so often borne of fear and lust-that intermediaries like Taifu feel so keenly.

Suetsumuhana's clueless misalignment with the injunctions to court, conceive, and continually compete for public and private favor, proposes the possibility of other knowledges and other modes of being. The misogyny and homophobia unleashed at her behavior attest to how her mode of dwelling in the world roils deep fears not simply about sexuality but about the very process of yoking one's life to a logic in which hope doesn't dominate. This is the reparative sense in which we should comprehend and affirm Suetsumuhana as "hopeless."

We might say, then, that Suetsumuhana enacts queerness in being singularly half-hearted. Without being stubborn, she doesn't bend easily; nor does she fetishize divergence from the norm. There's no fearsome embrace of deviance here; she just happens to prefer the textures of outmoded, grimy pelts and of stiffer glyphs on thick, fusty paper. If we forgo the furor she inadvertently incites, we can recognize in her rapport with these unpopular inanimate objects a tendency that drifts away from the trendsetting fervor of her peers but without precluding their 
exuberance completely. She doesn't scream "anti" but rather reads as a figure quietly living a style of celibacy that is besieged.

To be sure, Suetsumuhana's eventual capitulation indicates how precarious this style and spatiotemporal interval can be. However, rather than interpret this in terms of failure or success, I'm inclined to read it as but another twist among a litany of reorientations that she browses without buying into. After all, to turn from passé objects of questionable worth toward courtship's promise is not necessarily to surrender one's soul. One can go through the motions without careening out of habit or desperation. While Genji and Tō no Chūjō struggle to make successful courting more efficient, Suetsumuhana's queer disposition outlines an alternate style of apprehending and inhabiting the world that bypasses such values for the sake of a life that others view as less optimal. But that life is for her, by the same token, far more livable.

In moving to the following chapter, which examines how Genji grapples with the dislocation and dispossession of exile, we should keep in mind the benefits of Suetsumuhana's queer orientation toward intimacy and loss. 